\title{
THE EFFECT OF PROBLEM BASED LEARNING AND EXPOSITORY TOWARD LEARNING OUTCOMES OF CHRISTIAN EDUCATION COURSE
}

\author{
Rini Handayani \\ Student of Doctorate degree, \\ State University of Malang, Malang, Indonesia \\ e-mail: rinihandayanisaja@gmail.com
}

Learning strategy of problem based learning becomes one of the alternative strategies to improve the learning outcomes in understanding concept application for students who took Christian Education course. This strategy could encourage students to understand the concept of learning through contextual problem solving. The objective of this study examined the effect of learning strategies - Problem based learning and Expository, toward learning outcomes of understanding concept application among students who took Christian education course. The design of this study used quasi experimental with non-equivalent control group design pattern. The subjects were 107 students of the Faculty of Agriculture and Faculty of Humanities in Brawijaya University. The participants were divided into two groups, the experimental group (problem based learning) with 62 students and the control group (expository) with 45 students. The results of the study can be summarized as follows: (1) there was an influence of learning strategies on learning outcomes in understanding concept application among students who took Christian Education course in Brawijaya University, (2) Problem Based Learning strategies affected more in learning outcomes of understanding Christian Education concept compared to expository learning strategies, (3) Problem Based Learning strategies were learning strategies that bring significant influence on learning outcomes in relation with understanding of Christian Education concept.

Key words: learning strategies, problem based learning, expository, learning outcomes.

Стратегія проблемно-орієнтованого навчання стає однією 3 альтернативних методів покращення результатів щодо розуміння студентами концепиії християнськоӥ освіти. Ця стратегія могла б заохотити студентіВ до розуміння концепції навчання через вирішення проблем на практиці. Метою изого дослідження було вивчення впливу стратегій навчання на розуміння концепиії студентами, які пройшли курс християнської освіти. Під час дослідження Використовувався квазі-експериментальний метод для контрольної групи. В експерименті взял участь 107 студентів факультету сільського господарства та факультету гуманітарних наук $b$ університеті Вгашіјауа. Учасники було розподілено на дві групи: експериментальну групу, яка налічувала 62 студентами, 
та контрольну групу зі 45 студентами. В наслідок здійсненого дослідження можна зробити такий Висновок: спостерігається вилив стратегій навчання на результати розуміння та застосування концепції студентами, які пройшли курс християнського освіти $b$ університеті Вrawijayа; стратегї, що базуються на проблемно-орієнтованому навчанні, мають більший вплив на розуміння концепції християнської освіти $b$ порівнянні з роз'яснювальними стратегіями навчання; стратегї проблемно-орієнтованого навчання є такими, які інтенсифікують результати розуміння концепції християнської освіти.

Киючові слова: стратегії навчання, проблемно-орієнтоване навчання, обгрунтування, результати навчання.

\section{Introduction}

Education has a decisive role for individual development to face and respond to global competition (Simamora, 2010). Despite, the changing and developing of technology, social and economy also affect the forming of the individual itself. Simamora explained that education has purpose in providing environment for students. Students expand their potential in order to show their existence and function based on their personal and community necessities. However, the function of education, which supposed to be responsible to guide the character's development, was obstructed by problems in education. These problems appeared because teachers were still using the old way in delivering the lesson. Students, then, only knew the theory and had trouble in applying the knowledge after their graduation. This condition is also seen in the implementation of Christian Education course (PAK). Teachers were only giving the material without accompanying the students during the lesson. Hence students could not understand the concept of PAK and did not know how to apply the concept to their life.

If education was forced to push students in understanding and applying the concept to their life, PAK should apply a comprehensive learning strategy. In accordance with the statement of Indonesian Ministry of Education and Culture (2013) in Teacher's Book of Christian Education and Moral Education PAK had different curriculum structure, PAK became a tool in helping students meet Allah in personal. It also helped improve students' behaviour in daily activity that could be beneficial for other people, including teachers, friends, family, or society.

Related to the importance of understanding and applying the concept of PAK, Sopater (2000) argued that Christian Education should be capable in giving attention and recognizing students' development stages, including the physical, emotional, intellectual, social, aesthetic and spiritual aspect. Sopater (2000) also stated that the function of PAK was to control students' character development. PAK should be able to attract students' attention as a course that could answer all their questions while facing the challenges in their life.

Teacher must be creative in delivering PAK's learning strategy which met students' necessity. Indonesian Ministry of Education and Culture (2013) through Teacher's Book of Christian Education and Moral Education explained that every teacher is expected to be able to apply student cantered strategy rather than teacher cantered strategy in their lesson. PAK learning process is a process that endeavour students' learning through creative activities facilitated by a teacher. The competence of PAK is arranged to make the learning process and outcomes have result in the implementation and in the habitual behaviour which measured through the assessment based on the main competence criteria.

One of the alternative learning strategies that can avoid teacher cantered in learning PAK was problem based learning (PBL). According to Arends (2008), problem based learning is a learning strategy which provides some authentic problems to be investigated and 
examined. It enters real life's problem as a context for students to think critically and to solve problem, also as a knowledge and essential concept of the learning material (Sudarman, 2007). PBL also helps students to think critical and active in solving problems in their life based on the PAK's learning. Thus, this study focused on how far the influence between PBL learning strategy and expository learning strategy go toward learning outcomes in understanding the application of PAK.

2. Literature Review

2.1 Problem Based Learning

Problem based learning is a learning methodology that used problem in real life as a context in its learning. It allows students to learn on how to think critically and to have ability in solving problem (Sudarman, 2007). Smith \& Ragan (2001) in Rusmono (2012) said that PBL learning strategy is an attempt to shape the understanding process of a lesson in the whole curriculum. PBL offers students to have freedom of thought in the learning process. It involves students to work on problem in a small group which occurred in their daily life. This learning strategy has characteristics as below:

1) Driving question or problem

2) Interdisciplinary focus

3) Authentic investigation

4) Production of artefacts and exhibits

5) Collaboration

2.2 Expository Learning

Expository learning is a learning strategy which emphasizes the process of delivering material intended to make students mastering the material optimally. In this strategy, the learning material is directly delivered by teacher and students are not charged to find the material. Expository learning is also known as chalk and talk (Sanjaya, 2006) which has some characteristics as below:

1) Expository strategy is done verbally. It means that this strategy uses verbal as the main tool in delivering the material. Thus, most people identify this strategy as speech.

2) The material is already available, such as data or facts, and certain concepts that need to be remembered. Thus, it does not require students to rethink about the material.

3) The main learning objective is to master the material. Hence, after the end of the learning process, students are expected to understand the material by reviewing the material back.

4) The expository strategy is a learning form of teacher cantered approach. Teachers have dominant role in this strategy. Teachers are delivering the material in a structured way with expectation students could master the material well. The main focus of this strategy is students' academic achievement

3. Methodology

This study used quantitative experiment with artificial condition observation. Artificial condition was made and arranged by the writer to know the influence of an action toward attitude or to test the availability of the influence. This study applied quasi experiment design which made it impossible to randomly assign participants to all groups (Salkind, 2006). Quasi experiment is a pseudo-experiment which cannot fully control the sample's characteristic, but has possibility to control the existing situation (Rizani, 2008). This study used nonrandomized control group pre-test-post-test design which involved two groups: experiment group and control group. The subject of this study was group of 107 students of Agriculture Faculty and Humanities Faculty in Brawijaya University Malang, who took PAK as their course. The experiment group consists of 62 students and get problem based learning strategy as the treatment, while the control group contains of 45 students and gets 
expository learning strategy. The measurement was done before and after the treatment and the influence was measured based on the differentiation between early measurement and end measurement from both groups. Hadi (2004) stated that there were three measurements steps; 1) pre experiment measurement, 2) treatment, and 3) post experiment measurement. The stages of the research could be seen in figure 1 below;

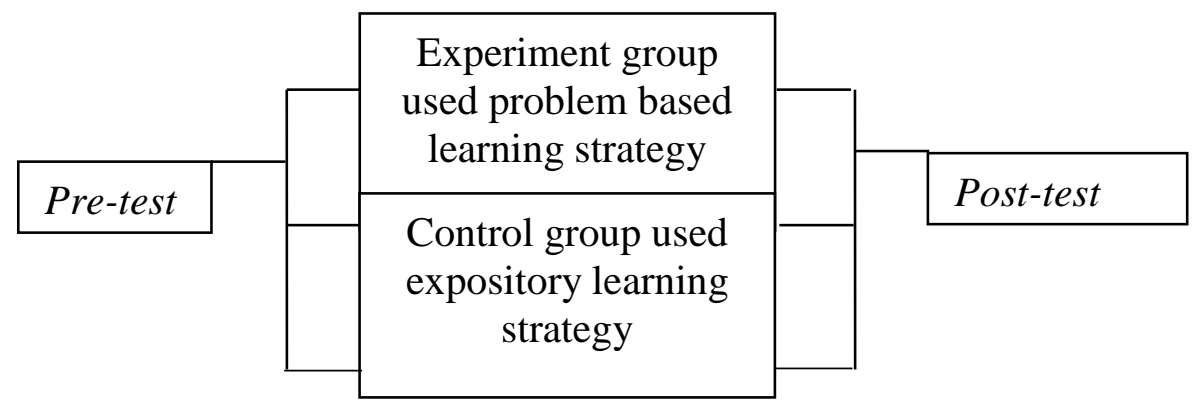

\section{Figure 1. Research Stages}

Here are the measurement steps:

a. First Stage: Pre Experiment Measurement

Before doing the treatment, students of experiment and control groups were given pre-test in the form of essay with Allah and Human as the subject matter.

b. Second Stage: Treatment

After the giving the pre-test, the next step is giving treatment. The experiment group was given PBL as the learning strategy, while the control group used expository learning as the learning strategy.

c. Third Stage: Post Experiment Measurement

In this step, the essay was giving back to students as the post-test. Thus, the results from the post-test were used to know the influence caused by the treatment.

3.1 Research Instrument

a). Procedure of Developing Instrument

This study used essay as the instrument to measure the understanding of PAK's concept application through students' learning outcomes. Essay had advantages to (1) develop and measure students' thinking ability, (2) push students to analyse their answer, (3) know students' level of understanding concept and applying material.

b). Instrument Validity Test

According to Azwar (2008), validity is the concept of measurement focused on accuracy and precision. The American Psychological Association, 1950 had done some variation of assessment in defining and scoring the validity, those are; 1 ) validity of content, 2) validity of construction, 3) validity of predictive, and 4) validity of concurrent. This study used validity of content or known as curriculum validity. Validity content was the valid measurement tool compatible to the curriculum content (Supranata, 2004).

Ancok (1987) mentioned that the most common way to know the validation of a measurement tool is by correlating the score from each item with total score. To get the coefficient correlation, Karl Pearson's Product Moment was used:

$$
r_{x y}=\frac{N\left(\sum x y\right)-\left(\sum x\right)\left(\sum y\right)}{\sqrt{\left\{N \cdot \sum x^{2}-\left(\sum x\right)^{2}\right)\left\{N \cdot \sum y^{2}-\left(\sum y\right)^{2}\right\}}}
$$

For Azwar (2008), the choice criteria were done based on the coefficient correlation of the 
total items with common limitation of rix $\geq 0.30$. This standard used in this study is considered to be valid due to its accuracy and precision. Therefore, if the correlation between score in each question and total score was under 0.30 , then the item was claimed as invalid.

c). Instrument Reliability Test

This study used reliability test with SPSS Release 21.0 program by using Alpha Cronbach as the methodology. The examination technic used Alpha Cronbach coefficient with 5\% standard. If the coefficient correlation was bigger than the critical score or the Alpha Cronbach score was bigger than 0.6 , then the instrument was claimed as reliable.

\subsection{Data Collection}

The data were obtained from pre-test and post-test learning outcomes demonstrated by the experiment and control class at some stages; 1 ) giving pre-test essay in the beginning of the investigation. It had purpose to measure students' understanding of PAK's application concept, 2) implementing the learning strategy in class, either the problem based learning or the expository learning, and 3) giving post-test to both group after giving the treatment strategy. The treatment was given in form of PAK lesson with PBL and SPE learning strategy for 12 meetings. Each meeting had 2 Credit Semester Systems (SKS) for 100 minutes, each SKS was 50 minutes. This treatment was done in April until June 2014 as seen in the table 1 below:

Table 1. Experiment and Control Group's Learning Activity

\begin{tabular}{|c|c|c|c|c|c|c|c|c|c|c|c|}
\hline \multicolumn{12}{|c|}{ Experiment and Control Group's Learning Activity } \\
\hline 1 & 2 & 3 & 4 & 5 & 6 & 7 & 8 & 9 & 10 & 12 & 13 \\
\hline \multirow[t]{2}{*}{$\begin{array}{l}\text { Pre- } \\
\text { test }\end{array}$} & \multirow[t]{2}{*}{$\begin{array}{l}\text { Introduct } \\
\text { ion }\end{array}$} & $\begin{array}{l}\text { KD } \\
1\end{array}$ & $\begin{array}{l}\text { KD } \\
2\end{array}$ & $\begin{array}{l}\text { KD } \\
3\end{array}$ & $\begin{array}{l}\text { KD } \\
4\end{array}$ & $\begin{array}{l}\text { Revie } \\
\mathrm{W}\end{array}$ & $\begin{array}{l}\text { KD } \\
5\end{array}$ & $\begin{array}{l}\text { KD } \\
6\end{array}$ & $\begin{array}{l}\text { KD } \\
7\end{array}$ & $\begin{array}{l}\text { Revie } \\
\text { W }\end{array}$ & \multirow[t]{2}{*}{$\begin{array}{l}\text { Post- } \\
\text { test }\end{array}$} \\
\hline & & $\begin{array}{l}\text { PBL } \\
\text { SPE }\end{array}$ & $\begin{array}{l}\text { PBL } \\
\text { SPE }\end{array}$ & $\begin{array}{l}\text { PBL } \\
\text { SPE }\end{array}$ & $\begin{array}{l}\text { PBL } \\
\text { SPE }\end{array}$ & $\begin{array}{l}\text { PBL } \\
\text { SPE }\end{array}$ & $\begin{array}{l}\text { PBL } \\
\text { SPE }\end{array}$ & $\begin{array}{l}\text { PBL } \\
\text { SPE }\end{array}$ & $\begin{array}{l}\text { PBL } \\
\text { SPE }\end{array}$ & $\begin{array}{l}\text { PBL } \\
\text { SPE }\end{array}$ & \\
\hline
\end{tabular}

Information:

KD : Basic Competence

PBL : Problem Based Learning Strategy

SPE : Expository Learning Strategy

4. Result

4.1 Pre-test Learning Outcomes

The students' pre-test result in both experiment and control groups was analysed using TTest statistical technique. This statistical analysis had aim to know the equality level of both groups. The pre-test of T-Test statistic could be seen in the table 2 below:

Table 2. Pre-test T-Test Group Statistic

\begin{tabular}{|c|c|c|c|c|c|}
\hline & Group & $\mathrm{N}$ & Mean/Average & $\begin{array}{c}\text { Std. } \\
\text { Deviation }\end{array}$ & $\begin{array}{c}\text { Std. Error } \\
\text { Mean/ } \\
\text { Average }\end{array}$ \\
\hline \multirow{2}{*}{$\begin{array}{l}\text { Pre-test } \\
\text { Learning } \\
\text { Outcomes }\end{array}$} & Control Group & 45 & 42.6889 & 8.32254 & 1.24065 \\
\hline & $\begin{array}{l}\text { Experiment } \\
\text { Group }\end{array}$ & 62 & 36.1290 & 9.01271 & 1.14462 \\
\hline
\end{tabular}

The table above showed that the average pre-test score of the control group was 42.68 
and 8.32 for the standard deviation. This score showed that the control group's average score was bigger than the experiment group's (36.12), while the standard score for the control group was smaller than for the experiment group (9.01).

The differentiation of the pre-test average score in both groups could not be the measurement to interpret that the pre-test score of the experiment group was significantly different or similar with the control group. Thus, in order to know the significant differentiation or similarity between the experiment and control groups, T-Test of two independent samples was used as seen in the following table 3:

Table 3. Independent Sample Test

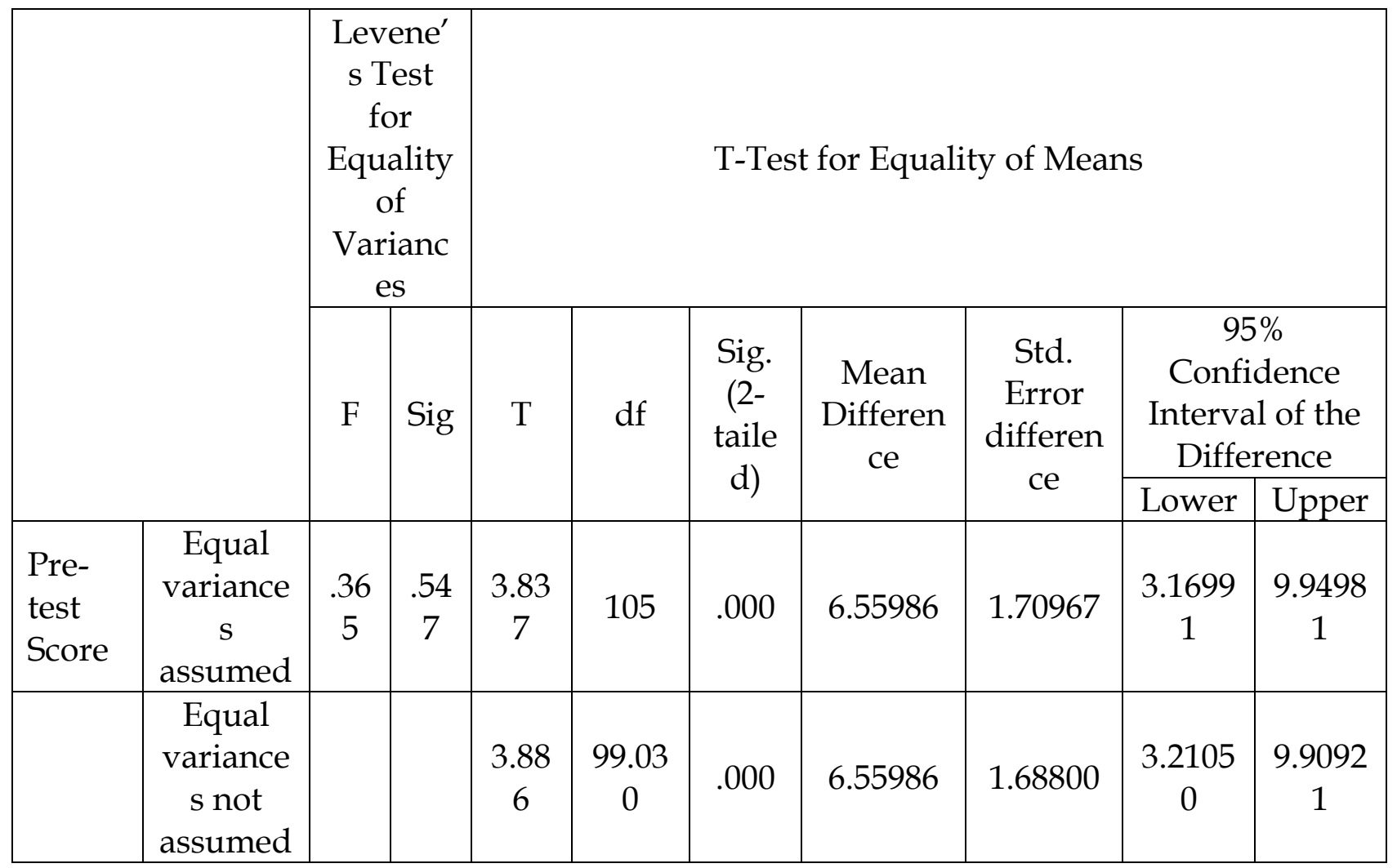

Based on the variant test in table 3 above, it showed that the Levene's test score was 0.385 with significant score $(p)$ of $0.547(p>0.05)$. It could be concluded that the variant data of students' pre-test learning outcomes was homogeny. The homogeny data, then, examined using T-independent test with equal variance assumed. T-Independent test result showed a significant score of students' learning outcomes in understanding the application of PAK which for the control group was 3.38 ( $\mathrm{p}>0.05)$. It meant that students' learning outcomes in understanding the application concept of PAK between the experiment and control groups had no meaningful differentiation $(\mathrm{p}>0.05)$, therefore Ho was accepted. Hence, both groups had equal ability. 


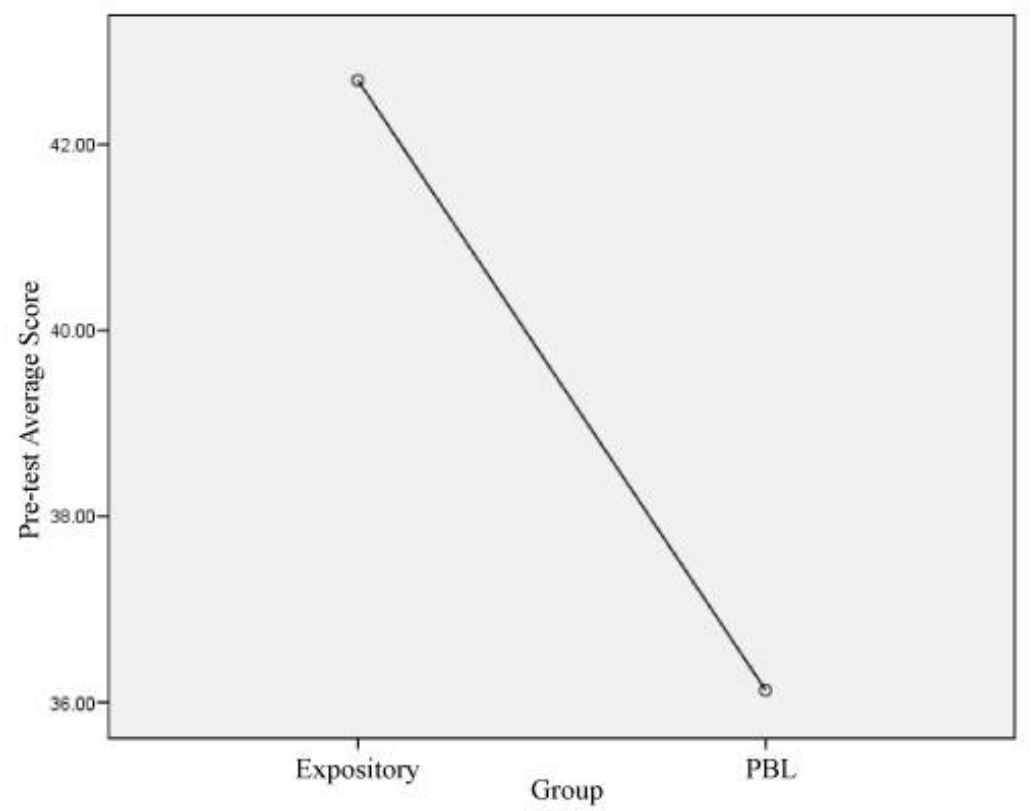

Figure 2. The Average Score of Pre-test Learning Outcomes

However, even though both of the experiment and control groups had equal abilities, the analysis result in post-test showed that the average score of the control group was 42.68 , which is higher than that of the experiment group - 36.12.

4.2 Post-test Learning Outcomes

Table 4. Post-test T-Test Group Statistic

\begin{tabular}{|c|c|c|c|c|c|}
\hline & Group & $\mathrm{N}$ & Mean/Average & $\begin{array}{c}\text { Std. } \\
\text { Deviation }\end{array}$ & $\begin{array}{c}\text { Std. Error } \\
\text { Mean/ } \\
\text { Average }\end{array}$ \\
\hline \multirow{2}{*}{\begin{tabular}{|l|} 
Pre-test \\
Learning \\
Outcomes
\end{tabular}} & Control Group & 45 & 42.6889 & 8.32254 & 1.24065 \\
\hline & $\begin{array}{l}\text { Experiment } \\
\text { Group }\end{array}$ & 62 & 36.1290 & 9.01271 & 1.14462 \\
\hline
\end{tabular}

From table 4 above, post-test's average score for expository learning class was 58.68 with standard deviation of 9.91. Meanwhile for problem based learning class, the post-test's average score was 80.85 with standard deviation of 13.25 higher than for the control group. The clear description of the average score in understanding the application concept through post-test could be seen in the following figure 3 below: 


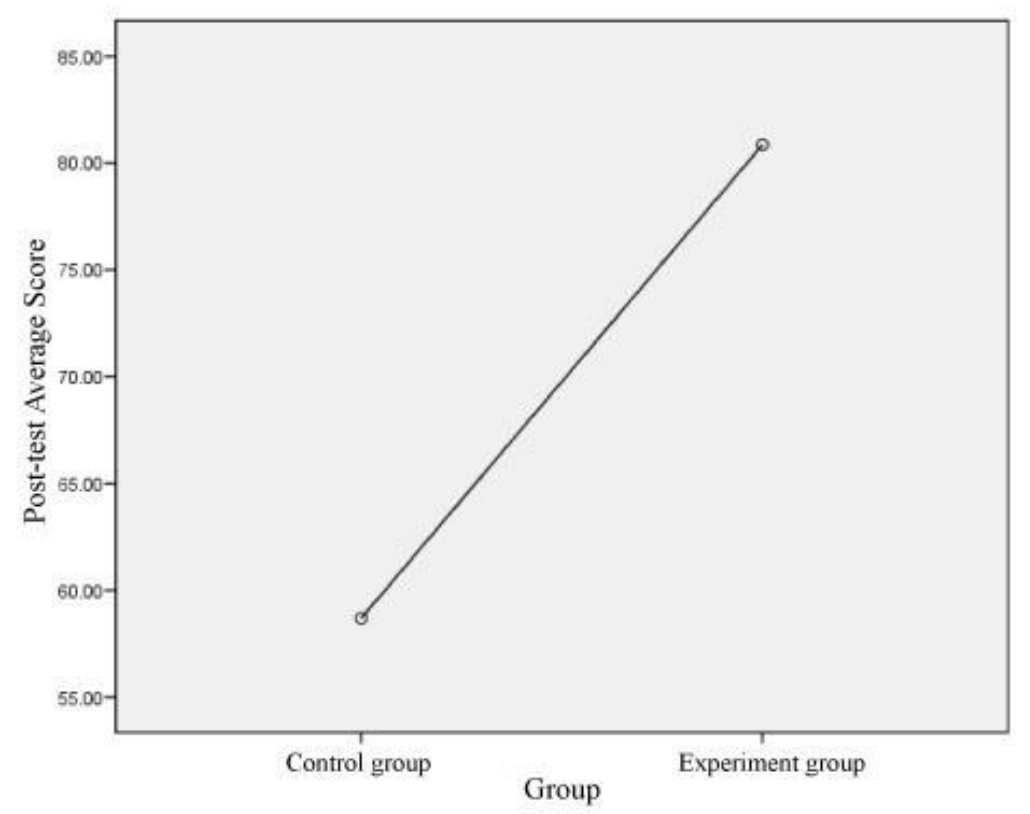

Figure 3. The Average Score of Post-test Learning Outcomes

Based on the figure 3 above, it could be seen that the average score of PAK's learning outcomes using problem based learning strategy was $(M=80.85 \pm S=13.25)$ higher than the average score from expository learning strategy $(M=58.68 \pm S=9.91)$. The differentiation of both strategies was significant, but still it needed a test result to know the differentiation of both learning strategies by using Paired Sample T-Test. Moreover, the differentiation between the control and experiment groups can be done by the Independent Sample T-Test.

4.3 Testing Hypothesis

4.3.1 Data Assumption Test

a. Normality of Data

Normal distribution was a theoretical distribution of random variable continuity. The curve was described the normal distribution in a symmetric curve. In order to test the sample, Kolmogorov-Smirnov Goodness of Fit Test was used.

Table 5. The Result of Data Normality Test

\begin{tabular}{|c|c|c|l|}
\hline Information & $\begin{array}{c}\text { K-S } \\
\text { stats }\end{array}$ & $\begin{array}{c}\mathrm{p}- \\
\text { value }\end{array}$ & \multicolumn{1}{|c|}{ Decision } \\
\hline $\begin{array}{c}\text { Expository Group's Pre- } \\
\text { test Score }\end{array}$ & 0.814 & 0.522 & Normal Data \\
\hline $\begin{array}{c}\text { Expository Group's } \\
\text { Post-test Score }\end{array}$ & 0.691 & 0.727 & Normal Data \\
\hline $\begin{array}{c}\text { PBL Group's Pre-test } \\
\text { Score }\end{array}$ & 0.774 & 0.586 & Normal Data \\
\hline $\begin{array}{c}\text { PBL Group's Post-test } \\
\text { Score }\end{array}$ & 0.935 & 0.346 & Normal Data \\
\hline
\end{tabular}

Source: Data Analysis

Based on the Kolmogorov-Smirnov's normality test, both of the variables in the control group and the experiment group had significant score, such as 0.522 , $0.727,0.586$ and 0.346 ( $p>0.05)$ which is acceptable. In summary, the score in pre-test and post-test of both groups was spread following the normal pattern. Thus, T-Test can be done.

b. Homogeneity of Data 
Santoso \& Tjiptono (2002) were using the Levine's test homogeneity of variances in order to detect the heterogeneity data. The data needed testing in this study was only the comparison between the control and experiment groups' score. The data was tested by independent sample test as in the table 6 below.

Tabel 6. The Result of Data Homogeneity Test

\begin{tabular}{|c|c|c|c|}
\hline Information & K-S stat & $\begin{array}{c}\mathrm{p}- \\
\text { value }\end{array}$ & Decision \\
\hline $\begin{array}{c}\text { Pre-test Score of } \\
\text { Expository and PBL } \\
\text { groups }\end{array}$ & 0.365 & 0.547 & homogeny \\
\hline $\begin{array}{c}\text { Post-test Score of both } \\
\text { Expository and PBL } \\
\text { groups }\end{array}$ & 2.825 & 0.096 & homogeny \\
\hline
\end{tabular}

Source: Data Analysis

Table 6 above showed difference in data demonstrated by the control and experiment groups (0.547 for pre-test and 0.0965 for post-test with $\mathrm{p}>0.05$ ). The variety of the compared data between the control and experiment groups during the pre-test and post-test were homogeny. Hence, the examination with independent TTest with equal variance assumed can be done.

4.4 Data Analyzes

a). Paired Sample T-Test

The result of paired sample T-test could be seen in table 7 below:

Table 7. Comparison Result between Pre-test and Post-test Score using Paired Sample T-test

\begin{tabular}{|c|c|c|c|c|c|}
\hline & \multicolumn{4}{|c|}{ Evaluation } & \multirow{3}{*}{$\begin{array}{l}\text { P score from } \\
\text { paired } \\
\text { sample T-test }\end{array}$} \\
\hline & \multicolumn{2}{|c|}{ Pre-test } & \multicolumn{2}{|c|}{ Post-test } & \\
\hline & Mean & $\pm S D$ & Mean & $\pm S D$ & \\
\hline $\begin{array}{l}\text { Control Group } \\
\text { (Expository) }\end{array}$ & 42.69 & 8.32 & 58.69 & 9.91 & 0.000 \\
\hline $\begin{array}{l}\text { Experiment Group } \\
\text { (PBL) }\end{array}$ & 36.13 & 9.01 & 80.85 & 13.26 & 0.000 \\
\hline
\end{tabular}

Source: Data Analysis

Taking into account the table 7 above, we can state that the control group had the average score of 42.7 for pre-test and 58.7 for post-test, while the experiment group had the average score of 36.1 for pre-test and 80.9 for post-test score. The students in the control group had significant score for 0.000 ( $\mathrm{p}<0.05$, Ho rejected) during the pre-test and post-test, which means there was a meaningful differentiation. Similar to the control group, the experiment group also had the significant score of $0.000(\mathrm{p}<0.05$, Ho rejected $)$ during the test, which showed meaningful differentiation. 


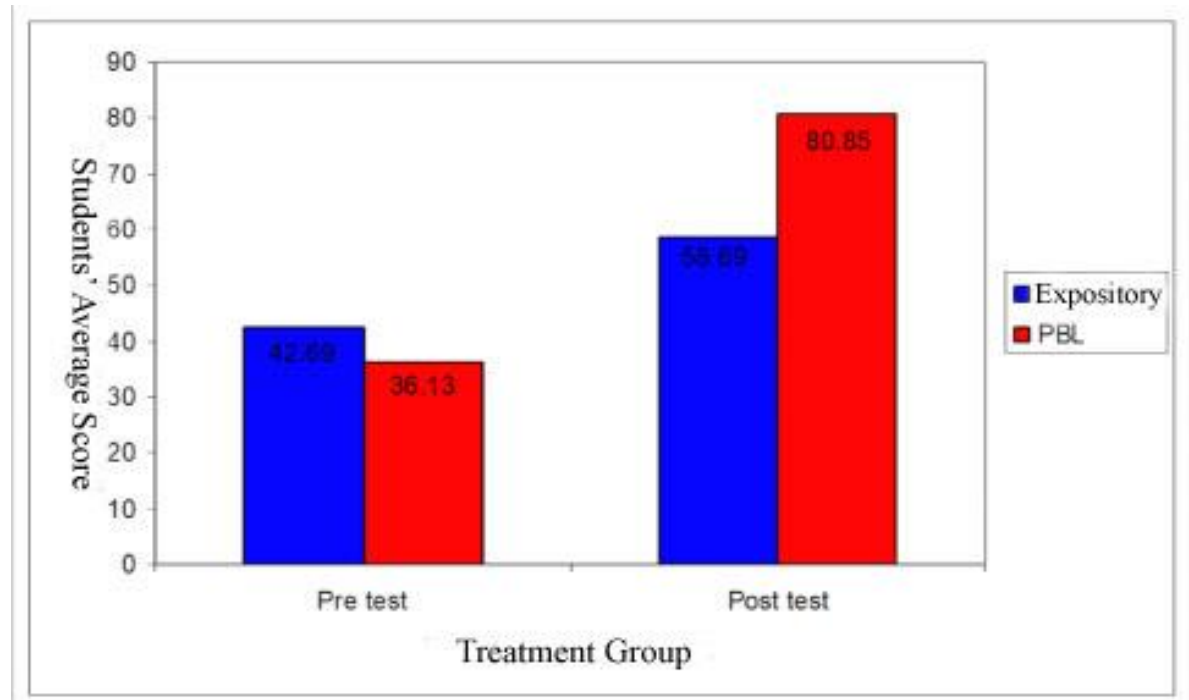

Figure 4. The graphic of average score and standard deviation

Figure 4 showed that the control group had higher score during the pre-test than the experiment group. While after the post-test, the experiment group had higher score than the control group.

b). Independent Sample T-Test

The average score was descriptively showed the differentiation between students' score in the control group and the experimental group. However, the independent T-test sample was needed to know the differentiation of both groups. The result obtained from the independent sample T-test could be seen in table 8 below:

Table 8. Comparison Result between Pre-test and Post-test Score using independent sample T-test.

\begin{tabular}{|c|c|c|c|c|c|}
\hline & \multicolumn{4}{|c|}{ Group } & \multirow{3}{*}{$\begin{array}{c}\text { P score } \\
\text { from } \\
\text { independent } \\
\text { sample T-test }\end{array}$} \\
\hline & \multicolumn{2}{|c|}{$\begin{array}{c}\text { Control } \\
\text { (Expository) }\end{array}$} & \multicolumn{2}{|c|}{$\begin{array}{c}\text { Experiment } \\
(\mathrm{PBL})\end{array}$} & \\
\hline & Mean & $\pm \mathrm{SD}$ & Mean & $\pm S D$ & \\
\hline Pre-test Score & 42.69 & 8.32 & 36.13 & 9.01 & 0.000 \\
\hline Post-test Score & 58.69 & 9.91 & 80.85 & 13.26 & 0.000 \\
\hline
\end{tabular}

It could be seen in the table 8 above that students' pre-test score of the control group was higher than of the experiment group, 42.7 compared to 36.1. But after the treatment, the post-test score showed that experiment group had higher score (80.85) than the control group (58.7). Hence, it can be concluded that there was score enhancement in post-test after the treatment using expository learning strategy for control group and PBL learning strategy for experiment group.

5. Discussion

The analysis above showed that students' pre-test score for control group was 42.7 higher than the score for experimental group 36.1. After giving the treatment on both groups, the post-test score of experimental group was higher (90.85) than of the control group (58.7). It proved that learning strategy applied after the pre-test had huge influences on students' leaning outcomes in understanding the application concept of PAK.

The result of independent T-test showed the significant score of the pre-test score between control and experiment group for $0.000(\mathrm{p}<0.05$, Ho rejected) which means there was a meaningful differentiation. In summary, both expository learning and PBL learning strategy could increase students' learning outcomes in understanding PAK's application 
concept. The paper also showed that the hypothesis was accepted with significant score of $0.000(\mathrm{p}<0.05)$.

Furthermore, this strategy had effect on students' learning outcomes in understanding the application concept of PAK. Even though the score enhancement could be the main indicator to prepare the learning strategy of PAK, but it must be meaningful. Significantly, the learning outcomes enhancement of the experiment group was more meaningful than that of the control group. Thus, significant enhancement could become an indicator that cantered learning strategy, by defining the contextual problem on the relevancy with PAK, helped students to understand more the concept of PAK and to apply it in their life.

\section{Conclusion}

In conclusion, we can state that there was an influence in learning strategy toward learning outcomes in understanding the application concept of PAK for Brawijaya University students. It was measured from the ratio between pre-test and post-test. The average score from expository group was 42.7 and increased to 58.7 after giving the expository learning strategy. The problem based learning group had average score of 36.1 in pre-test and it increased to 80.85 in post-test after using problem based learning strategy.

PBL learning strategy influences students' learning outcomes in understanding the application concept of PAK than the expository learning strategy. This was measured through the significant comparison of learning outcomes enhancement in the application concept of PBL with the enhancement of 44.75. It was bigger than the significant enhancement of expository learning which only increased for 16 points in average score. Therefore, PBL learning strategy brought the significant influence toward students' learning outcomes in understanding the application concept of PAK.

\section{References:}

1. Simamora, E. (2010). Pengaruh Pola Asuh Otoritatif dan Motivasi Berprestasi terhadap Kreativitas Mahasiswa. Tesis. Universitas Kristen Satya Wacana Salatiga. Program Psikologi Pendidikan.

2. Kementerian Pendidikan dan Kebudayaan. (2013). Buku Guru Pendidikan Agama Kristen dan Budi Pekerti. Indonesia

3. Sopater, S. (2000). Identitas dan Ciri Khas Pendidikan Kristen di Indonesia. Jakarta: BPK Gunung Mulia

4. Arends, R. (2008). Clasroom Instruction and Management, New York: Mc Graw-Hill Companies.

5. Sudarman. (2007). Problem Based Learning Suatu Model Pembelajaran untuk Mengembangkan dan Meningkatkan Kemampuan Memecahkan Masalah. Jurnal Pendidikan Inovatif Volume 2 Nomor 2 Universitas Mulawarman Samarinda.

6. Rusmono. (2012). Strategi Pembelajaran Dengan Problem Based Learning itu Perlu. Bogor: Ghalia Indonesia.

7. Sanjaya, W. (2006). Strategi Pembelajaran. Jakarta: Media Prenada

8. Hadi, S. (2004). Metodologi Research. Yogyakarta: Andi.

9. Salkind, N. J. (2006). Strategi Pembelajaran Berorientasi Standar Proses Pendidikan. Jakarta: Kencana Perdana Media.

10. Rizani, A.S. (2008). Meningkatkan Pemahaman Konsep siswa pada Pokok Materi Momentum, Impuls, dan Tumbukan dengan Pemanfaatan Multimedia Pembelajaran. Indonesia: PPS UIN

11. Azwar, S. (2008). Reliabilitas dan validitas. Yogyakarta: Pustaka Pelajar.

12. Ancok, D. (1987). Tehnik Penyusunan Skala Ukur. Pusat Penelitian Kependudukan UGM: Yogyakarta.

13. Santoso, S., \& Tjiptono, F. (2002). Riset Pemasaran Konsep\&Aplikasi Dengan SPSS, Jakarta: PT Elex Media Komputindo. 